\title{
A COMPARATIVE RESEARCH ON THE INVOLVEMENT OF COLLECTIVE BARGAINING IN SETTING WORKING TIME ACROSS FOUR EU COUNTRIES AND ITS IMPLICATION ON CHINA
}

\author{
Xiang $L i^{*}$
}

\begin{abstract}
Working time is one of the most important labor standards in industrial relations. It is also an important factor to reach work-life balance. Collective bargaining plays an important role in setting working time in many countries. Given that it is very rare to observe real collective bargaining in China, there is few comparative research covering EU member states and China in this field. This paper tries to fill in this gap by comparing the involvement of collective bargaining in working time regime in Sweden, the Netherlands, Germany, UK, and China. This paper classifies these five countries' working time regime, explores the orientations of their working time regimes, and investigates influencing factors. Then this paper lists the implication of four EU countries' working time regimes on China.
\end{abstract}

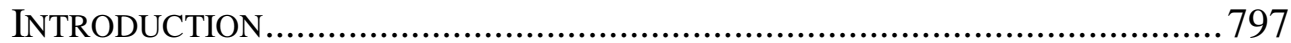

I. The CATEGORIES OF Working TIME REGIMES .................................... 798

A. Bargaining-Based Working Time ......................................... 798

B. Dual Systems' Working Time................................................ 798

C. "Voluntaristic" Working Time .............................................. 799

D. Legislation-Led Working Time ............................................. 799

II. THE ORIENTATION OF WORKING TIME REGIMES ...................................8 800

A. The Orientation of Swedish Working Time Regime................. 800

B. The Orientation of Dutch Working Time Regime ..................... 801

C. The Orientation of German Working Time Regime................... 801

D. The Orientation of British Working Time Regime .................... 801

E. The Orientation of Chinese Working Time Regime .................. 802

III. FACTORS INFLUENCING THE ORIENTATIONS OF WORKING TIME REGIMES
A. The Terminology Legislators Adopted ....
B. Workers' Involvement in Collective Bargaining ..................... 803
C. Collective Bargaining Structure ......................................... 804
D. Workers' Willingness to Trade for Compensation of Salary.... 805

\footnotetext{
* Ph.D. student of Leiden Law School in Leiden University of the Netherlands. Research fields: Labour Law, Collective Bargaining, Industrial Relation, and the Law of Gender. This paper is a revised version of a conference paper presented in an International Conference organized by Interuniversity Research Centre on Globalization and Work (CRIMT) on New Frontiers for Citizenship at Work in Montreal in 2014.
} 
IV. THE IMPLICATIONS OF FOUR EU COUNTRIES' WORKING TIME REGIMES

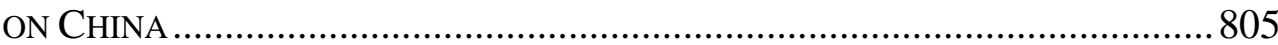

A. Collective Bargaining Should Be Encouraged in China .......... 806

B. Workers' Involvement Should Be Guaranteed in Collective

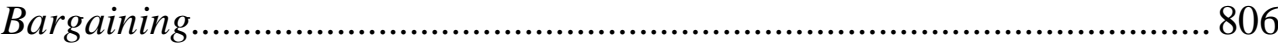

C. Collective Bargaining Should Be Placed at Industrial Level... 806

D. Workers'Solidarity Is Demanded ............................................. 807

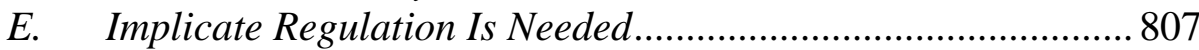

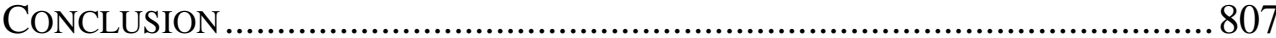

\section{INTRODUCTION}

Working time lies in the intersection of employment status and family life. It relates necessarily to other important social issues, for instance: conditions of work, industrial relations, gender gaps, work-life balance, health, social norms and international standards. According to the data of International Labor Organization (ILO), Chinese workers work averagely 46.6 hours every week in $2013 .{ }^{1}$ Given this survey does not cover workers in rural eras, the statistics may be more optimistic than the actual fact. Among all of the regions of the world, it seems quite safe to say that none of them has taken a greater interest in the subject of working time than Europe. ${ }^{2}$ From 1998 to 2015 , the average weekly working hour in the Netherlands steadily stay around 32. The gap between China and Netherlands highlights the necessities to explore the working time regime of EU countries.

Working time regimes are mainly shaped by two activities: Legislation and collective bargaining. Legislation can basically sets maximum and normal working hours, but legislation are usually too general for employees and companies. Collective bargaining can produce more practical and flexible labor standards. In the process of collective bargaining, social actors can conduct an agreement on extensive issues such as the overall numbers of working hours and the flexibility of working hours across industries.

As a system of autonomous social dialogue, the involvement of collective bargaining in setting working time regimes could directly influence to what extent working time regimes are employer-oriented or employee-oriented. The research question of this paper is to explore to what extent collective bargaining influences the orientation of working time

\footnotetext{
${ }^{1}$ The data is from ILO website. http://www.ilo.org/global/about-the-ilo/lang--en/index.htm.

${ }^{2}$ Messenger, Jon C., Working Time Trends and Developments in Europe, CAMBRIDGE Journal of ECONOMICS 296-297 (2011).
} 
regime and what China can learn from four EU countries' working time regimes. In the first part of this paper, it groups the categories of working time regimes in four EU member states and China into four categories based on the extent of the involvement of collective bargaining. In part two, it investigates the orientation of different working time regimes. In the third part, it explores factors influencing the orientations of these five countries' working time regimes. The fourth part lists the implication of other four EU countries' working time regimes on China.

\section{THE CATEGORIES OF WORKING TIME REgIMES}

The involvement of collective bargaining in setting working time regimes differs largely across countries. According to the extent of the involvement of collective bargaining on setting working time (descending order), related systems in four EU countries and China could be divided into the following four categories.

\section{A. Bargaining-Based Working Time}

In Nordic countries such as Sweden, collective bargaining is predominant to set working time regimes. The basis for this distinction is that collective agreements create legal rights and disputes. ${ }^{3}$ Legislation prescribes standards and maxima for the utilization of labor. Further limitations or even extensions, and the question of how permissible hours should be allocated are matters for collective bargaining. The legislation measures are to a great extent only semi-compulsory. ${ }^{4}$ Most provisions of labor market may be, wholly or partly, amended by collective agreements. ${ }^{5}$

\section{B. Dual Systems' Working Time}

In some old member states of EU, the roles of legislation and collective bargaining in setting working time are rather balanced. Regulations set the compulsory minimum conditions that have to be met with regard to working time. The collective agreements take these statutory as their basis and adapt them to the requirements of each industry or sector. The Netherlands and

\footnotetext{
${ }^{3}$ Torgeir Aarvaag Stokke and Christer Thornqvist, Strikes and Collective Bargaining in the Nordic Countries, EUROPEAN JOURNAL OF INDUSTRIAL RELATIONS 247-248 (2001).

${ }^{4}$ Axel Adlercreutz and Birgitta Nyström, Sweden, International Encyclopedia for Labour Law and Industrial Relations121-123 (2009).

${ }^{5}$ Dominique Anxo, Working Time Policy in Sweden, Working Time: In Search of New Research TERRITORIES BEyOND FleXIBILITy DEBATES 55-56 (2009).
} 
Germany are typical countries with dual systems. ${ }^{6}$ In the Netherlands, there is a long history of negotiating working time. As early as the 1982, the central unions and employers' organizations reached "Wassenaar Agreement", which regarded working sharing as an instrument to redistribute employment with the aim of solving the unemployment problem. Thereafter, there were another two rounds of working time reduction. ${ }^{7}$ Two complementary Dutch laws also played a lot in formulating current working time regime of Netherlands. ${ }^{8}$ Legislation and collective bargaining play roles in determining working time regimes in Germany. The negotiation on working time in Germany functions further than interpreting statutes. Collective agreements regarding working time are at least as important as the regulations themselves. Sometimes, collective agreements seven challenge regulations.

\section{C. "Voluntaristic" Working Time}

Anxo and O' Reilly define the flexibility of UK and Ireland as "voluntaristic" system. ${ }^{9}$ Considering the deregulated policy in UK labour market and the little involvement of regulations in working time systems, the involvement of collective bargaining can also be named with "voluntaristic" system. From the 1870s onwards, statutory regulations increasingly gave way to voluntary collective bargaining between employers and trade unions. Despite Working Time Regulation was made in 1998, it did not change the voluntaristic working time standards. Recently, the regulations of working time in UK still depended on collective bargaining rather than legislation. ${ }^{10}$

\section{Legislation-Led Working Time}

The working time regime in China could be counted as legislation-led

\footnotetext{
${ }^{6}$ Some scholars classify the systems of the Netherlands and Germany into two different systems given the different orientations of collective agreements. This paper groups the working time systems in these two member states to one category because theoretically both collective bargaining and legislation influence working time arrangements in these two countries.

${ }^{7}$ In 1994 and 1997, employers and unions of many sectors of the economy reached agreements about 36-hour working weekly in Netherlands.

${ }^{8}$ Working Hour Act of 1996 and Adjustment of Working Hours Act of 2000.

${ }^{9}$ Dominique Anxo and Jacqueline O'Reilly, Working Time Regimes and Transitions in Comparative Perspective, Working Time Changes: Social InTEGRation through Transitional Labour MARKETS 61-90 (2000).

${ }^{10}$ Catherine Barnard, Simon Deakin and Richard Hobbs, Opting Out of the 48-Hour Week: Employer Necessity or Individual Choice? An Empirical Study of the Operation of Article 18(1)(b) of the Working Time Directive in the UK, INDUSTRIAL LAW JOURNAL 226, 32.4 (2003).
} 
working time due to the little role of collective bargaining in setting working time regime. It is also well-known that trade unions in China are with little or no participation of workers' direct power. The collective bargaining system in China has already been changed into "collective negotiation" or "collective consultation" both in legal texts and practice. Collective bargaining pushed by workers' bottom-up pressure mainly focuses on wages. Working hours shown up in collective contracts in China usually are only duplication of what regulated in legislation. Labor Law (1994) and State Council's Regulation on Workers' Working Time (1995) underlines China's 40-hours and 5-workingdays weekly system.

\section{THE ORIENTATION OF WORKING TIME REGIMES}

The involvement of collective bargaining in setting working time influences the orientation of working time regimes. This section discusses the orientation of working time regime in above mentioned countries by analyzing their working time typologies. The orientation can be divided into employer-centered or employee-centered or both. The employer-centered orientation is embodied with the flexibility of labor force or longer working hours at a given pay. The employee-centered orientation is generally embodied at shorter working hours at a given pay, job security and the balanced work-life relations.

\section{A. The Orientation of Swedish Working Time Regime}

In Sweden, several long leave schemes (parental level, leave for care or illness in the family, leaves for training or education and leave for other purpose) have been reached. These schemes highly facilitate the needs of workers, especially when it comes to the clashes of working time and family time. Therefore, working time policies in Sweden have primarily been seen as means of creating a better balance and conciliation between paid work and other social activities rather than a remedy to imbalances in the labour market. ${ }^{11}$ However, long leave schemes distribute heavy burdensome to employers. Hence, it is challengeable for companies to keep competitive in a fast-moving world because these schemes offer less internal numerical flexibility to employers.

\footnotetext{
${ }^{11}$ Dominique Anxo, Working Time Policy in Sweden, Working Time: In SeArch of New Research TERRITORIES BEyond FleXIBILITy DeBATES 55-56 (2009).
} 


\section{B. The Orientation of Dutch Working Time Regime}

Given the guarantee of legislation and tripartite negotiations in the end of last century, the Netherlands has changed into the first part-time economy in the world. With the sovereign to adjust working hours, the large quantities of part-time workers facilitate the realization of employers' numerical flexibility. In the meantime, part-time work also helps workers to deal with work-life balance. Thus Dutch working time regime could be described as win-win working time regime, which means it is not only employer-oriented but also employee-oriented.

\section{The Orientation of German Working Time Regime}

In Germany, despite the overall ban on working on Sundays and public holidays, there are collective agreements where they are in fact allowed. ${ }^{12}$ The low efficiency on implementing these stipulations furnishes employers the possibilities to invade workers' statutory resting time and holidays. Consequently, workers' actual working hours are longer than agreed working hours. This cannot be separated from the defective implementing mechanisms in Germany. Overtime work is a normal phenomenon in Germany. As such, working time regime in Germany could be counted as employer-oriented.

\section{The Orientation of British Working Time Regime}

UK has been criticised a lot for the abuse of the individually opt out of 48-hour week and zero-hour contract system. The flexibility to work longer conducted by the employer is extremely employer-centered, while workers' work-life balance cannot be ensured. ${ }^{13}$ This contributes to the long working hour regime in UK. The zero-hour contract appeared in recent years indicates that workers' job security has been decreasea to a lowest level. ${ }^{14}$ Thus, working time regime in UK is very employer-oriented.

\footnotetext{
${ }^{12}$ Reinhard Bispinck, Germany: Working Time and Its Negotiation, ColleCtive BARGAINING ON Working Time: ReCENT EUROPEAN EXPERIENCES, ETUI-REHS, Brussels (2006).

${ }^{13}$ Catherine Barnard, Simon Deakin, and Richard Hobbs, Opting Out of the 48-Hour Week: Employer Necessity or Individual Choice? An Empirical Study of the Operation of Article 18 (1)(b) of the Working Time Directive in the UK, INDUSTRIAL LAW JOURNAL 226, 32.4 (2003).

${ }^{14}$ Matthew Pennycook, Giselle Cory and Vidhya Alakeson, A Matter of Time: The Rise of ZeroHours Contracts (London: Resolution Foundation 2013).
} 


\section{E. The Orientation of Chinese Working Time Regime}

China is a typical country where overtime widely exists despite that the statutory standard working hour is only 40 hours one week. The implementation of legislation has been undermined by fierce competition in the labor market. It is also caused by workers' willingness to overtime work due to their needs of supporting family. The difficulties to carry out real collective bargaining make China an attractive place for foreign investments. The flexibility to work longer has already become a main strategy for employers to keep competitive in globalization.

As demonstrated here, the variety of the involvement of collective bargaining in four categories result in working time regimes with different orientations. Even countries with same working time regime may lead to contrary orientation (Table 1).

Table 1 The Orientation of Working Time Regimes of Four EU Countries and China.

\begin{tabular}{|c|c|c|c|c|}
\hline Categories & $\begin{array}{l}\text { Typical country/ } \\
\text { countries }\end{array}$ & Main Working time typologies & $\begin{array}{l}\text { Employee- } \\
\text { Centered }\end{array}$ & $\begin{array}{l}\text { Employer- } \\
\text { Centered }\end{array}$ \\
\hline $\begin{array}{l}\text { Bargaining-based } \\
\text { workingtime }\end{array}$ & Sweden & $\begin{array}{l}\text { Long leave schemes (parental, } \\
\text { care, training/educational) }\end{array}$ & $\sqrt{ }$ & \\
\hline \multirow{2}{*}{$\begin{array}{l}\text { Dual systems' } \\
\text { working time }\end{array}$} & The Netherlands & Part-time jobs & $\sqrt{ }$ & $\sqrt{ }$ \\
\hline & Germany & Overtime & & $\sqrt{ }$ \\
\hline $\begin{array}{l}\text { "Voluntaristic" } \\
\text { workingtime } \\
\end{array}$ & UK & $\begin{array}{l}\text { Long working hours and zero- } \\
\text { hour contracts }\end{array}$ & & $\sqrt{ }$ \\
\hline $\begin{array}{l}\text { Legislation-led } \\
\text { working time }\end{array}$ & China & Overtime & & $\sqrt{ }$ \\
\hline
\end{tabular}

\section{FACTORS INFLUENCING THE ORIENTATIONS OF WORKING TIME REGIMES}

Above analysis demonstrates that generally, the more collective bargaining involved in setting working time, the more employee-centered it is. Thus, collective bargaining desires more attention than legislation in researching working time regimes. Collective bargaining institution includes many factors. The following section lists four of them and gives explanations on these four factors.

\section{A. The Terminology Legislators Adopted}

The concept of collective bargaining legislators adopts reflects legislators' attitudes on collective bargaining. There is an obvious divergence about the concept of collective bargaining between the Marxian and non-Marxian, in other words, EU countries' legislators and Chinese 
legislators. To the Marxist proponents, collective bargaining is a "dialectic" response of the working class to capitalism. ${ }^{15}$ The conflicts between working class and capitalism are irreconcilable. After the collectivization of 1950s, the conflicts between working class and capitalism are supposed to have been disappeared in China. With the deepening of the reform, the ruling party regards conflicts between workers and employers as the inner conflicts within the same class, reconcilable conflicts. The term of "collective consultation" sounds moderate and more acceptable to Chinese legislators. In current legislation, it is seldom to observe the term of "collective bargaining", but it is frequently perceived "collective consultation".

For non-Marxian, collective bargaining is viewed as a key institution of pluralistic society which owns its rationale to the paradoxical character of an employment relationship as one of "antagonistic cooperation". ${ }^{16}$ Thus, the concept of collective bargaining in four EU member countries is different from the term Chinese legislators use. It is more possible to see real collective bargaining in EU countries.

\section{B. Workers' Involvement in Collective Bargaining}

Theoretically, the higher the trade union density is, the more employeecentered working time regime is. However, it is not always true if we look at trade union density of Chinese workers. According to the official data, trade union density in China is very high $\left(96.13 \%\right.$ in 2013) ${ }^{17}$ However, it is also widely accepted that workers are seldom involved in trade unions, and workplace trade unions are generally under the control of employers. According to Article 51 of Labour Contract Law (2008), only trade unions (or representatives elected under the guidance of higher-level union in enterprises without trade unions) are legally allowed to bargain with the employer at enterprise level. Thus, Chinese workers have little chance to get involved in collective bargaining. In UK, the trade union recognition process sets invisible threshold for trade unions, which is the collection of workers' power, to get participate in collective bargaining. Thus, workers cannot involve too much in collective bargaining in UK. In Nordic countries,

\footnotetext{
${ }^{15}$ Perry Anderson, The Limits and Possibilities of Trade Union Action, in The InCOMPATIBLES: Trade Union Militancy and the Consensus (R. Blackburn \& A. Cockburn eds., Harmondsworth: Penguin, 1967).

${ }^{16}$ Malcolm Warner and Ng Sek-Hong, Collective Contracts in Chinese Enterprises: A New Brand of Collective Bargaining under 'Market Socialism'?, BRITISH JOURNAL OF INDUSTRIAL RELATIONS 299300, 37.2 (1999).

${ }^{17}$ The data is from China Statistical Yearbook complied by National Statistics Bureau.
} 
the highly unionized representation can group workers' power to the largest degree. ${ }^{18}$ Thus, workers power can be involved in collective bargaining to a large degree. In Germany, "the institutions of works councils can negotiate with a firm on non-wage work-place conditions". ${ }^{19}$ However, the role of works council in Germany is debatable. On the one hand, it can contribute to mediate the side effect of globalization. On the other hand, the codetermination between works councils and the employer decays the binding effects of collective agreements at upper level. ${ }^{20}$ Thus, workers' power might be decreased in collective bargaining in Germany. Dual channels of legislation and collective bargaining like in the Netherlands are more possible to incorporate workers' willingness in Collective bargaining. It can combine primary standards (trade unions are involved in negotiating primary standards) with flexible arrangements (works councils involved in the process of bargaining flexible arrangements). Thus, workers' involvement in collective bargaining of Netherlands is largely guaranteed.

\section{Collective Bargaining Structure}

Generally, the higher is collective bargaining structure, the more employee-oriented the working time regime is, since worker' power at central level are strong enough to countervail employers. The lower of bargaining level is, the more employer-oriented it turns out to be since workers' power at enterprise level might not be strong enough to countervail the pressure from employers. This basically explains the orientation of Nordic and British working time regimes. Industrial level collective bargaining is more possible to reach win-win collective agreement, since it could group workers' power to a larger extent, and it also allows flexibility. The orientation of Dutch working time regime can be explained by this rule. The bargaining structure of China is mainly dominated by enterprise level bargaining. Even if workplace trade unions get rid of their dependence on enterprises in China, enterprises level bargaining is less likely to reach employee-oriented working time regime compared with industrial level bargaining. If employers find the labor standards in other enterprises are

\footnotetext{
${ }^{18}$ According to the data of ETUI, trade union density in Sweden is around $70 \%$. The data is available at http://www.worker-participation.eu/National-Industrial-Relations/Across-Europe/Trade-Unions2.

${ }^{19}$ Claus Schnabel, Stefan Zagelmeyer and Susanne Kohaut, Collective Bargaining Structure and Its Determinants: An Empirical Analysis with British and German Establishment Data, EUROPEAN JOURNAL OF INDUSTRIAL RELATIONS 12.2 (2006).

${ }^{20}$ Brian Burgoon and Damian Raess, Globalization and Working Time: Working Hours and Flexibility in Germany, Politics \& SocieTy 554-575, 37.4 (2009); Hartmut Seifert and Heiko Massa-Wirth, Pacts for Employment and Competitiveness in Germany, IndustRIAL RELATIONS JOURNAL 217-240, 36.3 (2005).
} 
more employer-friendly, employers might less likely to make compromise. This is because employers also have the option of recruiting new workers. Thus, low level bargaining structure is also one of reason resulting in employer-friendly working time regime in China.

\section{Workers' Willingness to Trade for Compensation of Salary}

In four EU countries, the bargaining process for workers is generally an instrument to tailor their own working hour to realize work-life balance. In developing countries, generally, the need to survive, or to support their family members is workers' main concern. Workers have to subordinate working hours to salary, since the latter one deal with their necessity of survival. This also happen to China. Currently, a majority of Chinese workers still focus on the pay increase. They are usually voluntary to work overtime to get overtime salary. Collective bargaining on working time is rarely observed. If there is collective bargaining on working time, workers' demands are usually defending their legal rights or asking for the compensation for overtime work. Workers' willingness to work overtime is one of important factor contributing to overtime work in China.

\section{The IMPLICATIONS OF FOUR EU COUNTRIES’ WORKING TIME REGIMES ON CHINA}

Considering the widely use of overtime and the weak role of individual workers in labor market in China, it is urgent to take collective bargaining to protect workers. The Honda Strike in 2010 symbolizes the waking up of Chinese workers. Collective bargaining has already emerged in China. According to the statistics of China Labor Bulletin, ${ }^{21}$ workers' demands over collective bargaining are getting diversified. Working time reduction will probably become an important area for workers to struggle after workers' salary is achieved. Given that Chinese workers have already woken up, it is unwise to wait for workers to upstream their rights and interests by making riots. A proper collective bargaining might contribute to reach balanced labor-capital relations. However, improper collective bargaining may not result in the reduction of labor unrest, but may bring in the surge of wildcat strikes. Hence it needs to be cautious in designing collective bargaining in China. The working time regime of these four EU countries gives some implications on China.

\footnotetext{
${ }^{21}$ This database provides information about strikes happened in China since 2011. The website of this data base is http://maps.clb.org.hk/strikes/en.
} 


\section{A. Collective Bargaining Should Be Encouraged in China}

Compared to legislation, collective bargaining could serve more for balanced industrial balance. There are several reasons. Firstly, legislation might be too employer-friendly or employee-friendly. Either kind of orientation could lead to legislation be impractical. Employers may bypass the law if they are distributed with too many burdens by the law. Employees might resort to labor insurgence if the law cannot grant them with effective remedies mechanisms. Secondly, legislation might not be flexible and practical enough for all industries. However, collective bargaining could allow some flexibility. Thus, collective bargaining could also save legislative cost. Thirdly, through collective bargaining, workers can directly involve in deciding the value of labor. Hence, legislators shall encourage collective bargaining and develop it as a long-term strategy to maintain industrial harmony in China.

\section{B. Workers' Involvement Should Be Guaranteed in Collective Bargaining}

Workers' adequate involvement in collective bargaining is important in collective bargaining. Workers' adequate involvement in collective bargaining is a precondition that workers participate in deciding their labor force. It is also the condition to guarantee collective bargaining reflects workers' willingness. It is also the premise that workers observe collective contracts. Workers' involvement is the vital factor that why working time in Nordic countries is very employee-friendly. This can be achieved by granting workers the right the organize trade unions or allowing workers democratically participate in trade unions. If workers are not granted with enough space to get involved in trade unions, workers might bypass trade unions and resort to self-saved method, such as wildcat strikes, to address their grievance.

\section{Collective Bargaining Should Be Placed at Industrial Level}

The implication of working time regime of four EU countries indicates that collective bargaining of China needs to be placed at industrial level. Collective bargaining at industry level is more easily to satisfy the continuous requirements of flexibility of employers and employees at the same time. In addition, it is more possible to realize industrial-level collective bargaining than central level collective bargaining in China, because the bargaining level in China still remains at the enterprise level. The transition from enterprise level to industrial level is more practical to be 
realized compared with the transition from enterprise level to central level. The implication of UK also indicates that decentralized collective bargaining is less possible to countervail the pressure from employers. Thus, it is necessary to centralize collective bargaining in China given that trade unions' dependence on enterprise management at the enterprise level.

\section{Workers' Solidarity Is Demanded}

Workers' solidarity through collective bargaining is also very important. Chinese workers are getting used to overtime work to trade for the increase of the salary. It is impractical to persuade individual Chinese workers to say no to overtime work due to their pressure of survive. However, it is possible to reject employers' requirement of overtime work during collective bargaining since collective bargaining could group workers' individual power. This requires workers' solidarity during the bargaining process. Workers' solidarity is an essential ingredient to reach employee-oriented working time. Chinese employers are also getting used to "divide and conquer" workers' solidarity in dealing with workers' demands. This requires workers to reinforce their determination of 'solidarity' to overcome the dispersion from employers.

\section{E. Implicate Regulation Is Needed}

The explicit and imperative stipulations about the binding effect of collective agreements are necessary. The binding effect of collective agreements can determine to what extent collective agreements can be implemented. Without clear implementing and monitoring mechanisms, the collective agreements are meaningless since what regulated in collective agreement can be not guaranteed. The gap between agreed working hours and actual working hours in Germany also indicates the importance of imperative implementing mechanisms of collective contract.

\section{CONCLUSION}

For workers in developing countries like China, working hour is usually not their main concern among all working conditions. It is possible to observe that Chinese workers are voluntary to asking for overtime work to trade for the statue of "being employed"; or else they may lose their job and cannot survive. Some Chinese workers do overtime work because they need the compensation fee for overtime work to support their family members. The imbalanced labor-capital relations in China contribute to the 
longtime work in China. However, since 2010, Chinese workers' image of "being tolerant and docile" have been broken up. Working time is very likely to become workers' top demands after their salary is achieved. The comparative analysis of the working time regime in four representative EU countries implies that collective bargaining should be developed in China. Collective bargaining is a long-term structure to reach industrial harmony. However, the design of collective bargaining in China should be cautious, since improper collective bargaining institution might bring in the surge of wildcat strikes. Workers' involvement should be guaranteed in collective bargaining; otherwise workers might not feel binding by the collective contract. This could be done by allowing workers democratically involve in trade unions. In addition, collective bargaining should also be placed at industrial level. Central level collective bargaining is conducive to produce too employee-friendly working time, while enterprise level collective bargaining may result in employer-friendly working time. Workers should also form solidarity in case employers use the strategy of "divide and conquer" to break workers' solidarity. Last but not least, the implicate regulation on the binding power of collective bargaining is needed. If not, it may result in the huge gap between agreed working hours and actual working hours. 